\title{
Forest management scenarios modelling with morphological analysis - examples taken from Podpolanie and Kysuce
}

\author{
Rudolf Navrátil ${ }^{1,2}$ *, Yvonne Brodrechtová ${ }^{1}$, Róbert Sedmák ${ }^{1}$, Ján Tuček ${ }^{1}$ \\ ${ }^{1}$ Technical University in Zvolen, Faculty of Forestry, T. G. Masaryka 24, SK - 96053 Zvolen, Slovak Republic \\ ${ }^{2}$ Czech University of Life Sciences Prague, Faculty of Forestry and Wood Sciences, Kamýcká 1176, \\ CZ-165 21 Praha 6 - Suchdol, Czech Republic
}

\begin{abstract}
Scenarios modelling offers to forest management an option how to envision complex future associated with various natural, social, or economic uncertainties. The challenge is what modelling method to choose as many methodological approaches to scenario building exists. Morphological analysis is a basic modelling method for structuring and analysing a whole set of relationships existing in multi-dimensional, non-quantifiable, and complex topics. Especially, its application is relevant when abstract policy or market-driven challenges need to be investigated. In this study, we demonstrated the usefulness of the morphological analysis with an example case taken from forest management in Slovakia. The use of the method has enabled, from a number of uncertain futures, to identify three possible, plausible and consistent future scenarios of possible forest management direction in the regions of Podpolanie and Kysuce. Additionally, the future scenario modelling as prognostic method of qualitative research supported by quantitative models or forestry DSS could introduce participation and more dimensions into forest management modelling. Thus, the future scenarios modelling offers new methodological possibilities to how to deal with increasing uncertainties associated with increasing demands for various ecosystem services or negative impacts of climate change, that forest management in Slovakia will face in the near future.
\end{abstract}

Key words: forest management; future variations; coherence of scenarios; consistency matrix; cluster map

Editor: Róbert Marušák

\section{Introduction}

Although the term "scenario" comes from the field of dramatic art, from a prognostic point of view, it is a method of predictive analysis to forecasting the future pioneered by Kahn (Glenn \& Gordon 2009). Future scenarios, originally developed for military planning purposes and later adapted by business world, have emerged since the late 1990 s as an important tool in environmental analysis and policy formulation (Evans et al. 2008). Scenarios offer an excellent option for how to deal with uncertain future for which we have to make decisions today. They do no forecast the future-the most probable one- but rather search for multiple plausible futures.

Scenarios have been also used in assessing future forest management, which faces uncertainties mainly associated with changing the climate, socio-economic conditions, or technological developments (Hoogstra et al. 2017). Therefore, in the forest management, the scenarios could be used for illustration of the trade-off between ecosystem services, evaluation of different forest management practices, and/or assessment of potential future developments (e.g. Nordström et al. 2013; Korosuo et al. 2014; Albert et al. 2015; Carlsson et al. 2015; Hengeveld et al. 2017). Future scenarios method is often used also as a means of communication in initiating discussions with the public and stakeholders (Gaßner \& Steinmüller 2004). Wollenberg et al. (1999, 2000) identified future scenarios as a tool encouraging the cooperation of forest owners, managers and stakeholders. The scenarios can be implemented in a participatory manner as a workshop-based activity with the participation of forest owners, decision makers and other stakeholders. The method stimulate dialogue in the searching for barriers and driving forces of further development as well as in planning processes (Evans et al. 2008). In recent years, the forestry sector in Slovakia has to deal with changing climatic and environmental conditions and higher demands of the public for forest products and ecosystem services. So, future scenarios implemented by a participatory approach could be an 
appropriate response to the ever-increasing public call for sustainable forest management. What is also confirmed by the fact that public participation in sustainable forestry in Slovakia is still very formal and difficult (Kovalčík et al. 2012; Sarvašová et al. 2014; Sarvašová 2016).

The challenge for the scenarios modelling is how to capture the complexity of the world. In order to inspire and influence the decision making, scenarios must be sufficiently reliable and consistent. Many different methodological approaches to how to deal with scenarios modelling exist (e.g. Bishop et al. 2007; Amer et al. 2013), also with various application in the field of forest management (e.g. Hoogstra et al. 2017). Bishop et al. (2007) described eight general categories (types) of scenario modelling techniques including those that deal with dimensions of uncertainty - GBN matrix (Schwartz 1991) and morphological analysis. By applying of these techniques, the scenarios are constructed by first identifying the sources of uncertainty that are the basis for alternative futures, depending on how the uncertainties play out. While GBN matrix of four cells represents alternatively the four combinations of the poles of the two uncertainties, the morphological analysis matrix contains any number of uncertainties and any number of alternative states for each uncertainty. Morphological analysis allows to narrow down all possible combinations by deciding which combinations of uncertainties (factors) and alternatives (variations) are plausible and important in modelling consistent scenarios for the future (Heinecke 2006).

Although a large number of possible combinations can be considered as a disadvantage of morphological analysis, there are several sophisticated software tools overcoming the problem. Some of the best-known tools in the field of morphological analysis and future scenarios modelling are Morphol (Godet \& Roubelat 1996), Casper (Eriksson \& Ritchey 2002) Godet Toolbox (2003), Scenario Analysis Tool Suite (Dilek 2009) or Parmenides EIDOS tool suite provided by Parmenides Foundation.

The goal of this paper is to present an application of future scenario modelling technique - morphological analysis in the development of forest management scenarios in two Slovak regions of Podpolanie and Kysuce. The uncertainties - drivers and barriers affecting forest management in both regions were derived with the help of participatory manner by in-person interviews and structural analysis presented in previous papers (Navrátil et al. 2016; Brodrechtová et al. 2018). In this paper we present the method of examining possible, credible and plausible future alternatives of these derived uncertainties. Attention is paid to the process of assessing the overall consistency and coherence of scenarios implemented with the strong support of analytical functions of Parmenides EIDOS tool suite. As the result, three possible future scenarios of forest management presented in a short description were developed for each region.

\section{Morphological analysis in general}

The general morphological analysis is a basic, conceptual (non-quantified) modelling method for structuring a conceptual problem space - called a morphospace - and, through a process of existential combinatorics, synthesising a solution space (Ritchey 2018). More precisely, the goal of the method is in identifying and structuring all possible factors and solutions for non-reducible, complex problem spaces that often include human behaviour and political aspects (Johansen 2018).

The morphological process characterized by repeated sequences of analysis and synthesis generally moves ahead in five distinct steps (Johansen 2018). The first one is based on the detailed formulation of the problem while acknowledging that a precise definition of the issue might be unlikely. Within the second step, the defined problem is split into factors that set boundaries to it. Each factor must be carefully selected and characterized by a set of possible variations. The third step is crucial as the morphological box is designed. This box also called multidimensional matrix represents all combinations of the factors and their variations. As some combinations are inconsistent or impossible-called also a problem space-, in the fourth step this space needs to be reassessed. In the search for a solution space, the consistency of the combinations is checked. Generally, consistency is assessed according to two criteria: (1) logical consistency-internal relations of the factors cannot be contradictory, and (2) empirical consistency- solution should not be empirically impossible (Amer et al. 2013; Johansen 2018). In the final fifth step the remaining solution space is surveyed and the best solutions - scenarios are selected.

Overall, Ritchey (2018) pointed the advantage of morphological analysis in recognizing new relationships or configurations, which may not be so evident and which we might have overlooked by less systematic methods. Importantly, it encourages the identification and investigation of boundary conditions, i.e. the limits and extremes of different contexts and factors.

\section{Application of morphological analysis}

\subsection{Definition of the problem}

As it is difficult to describe a future forest management in a holistic way, scenarios modelling has to focus on specific factors and omit issues that might be of relevance in other research contexts. In this respect it was essential to define the time horizon, the scenario-space via thematic coverage and the geographical scope (Greeuw et al. 2000; van Notten et al. 2003).

In the study we were concerned with assessment of possible future direction of forest management in the regions of Podpolanie and Kysuce. Both case study areas (CSAs) represent traditional agricultural-forest regions in Slovakia with more than $50 \%$ of forest cover. 
The territories have varied forms of land use such as forests, arable land, meadows, wetlands and dispersed as well as concentrated settlements. Significant parts of both regions belong to the network of protected areas. The forest ownership structure, health status, and current structure of forest stands are the biggest contrasts between the two CSAs. Considering the similarities and differences, the territories were chosen for application of future forest management scenarios modelling. Specifically, we described the forested landscape future and the development of the path from the present (2010) to the future forest management in 2040 while considering the influence of ecological, socioeconomic and political factors. Taking into account the comparatively slowchanging system of forests the time horizon of 30 years can be considered as a short- or medium-term approach. The task was to create three possible, credible and mutually different future scenarios indicating possible forestry development over the next 30 years in each CSA.

The process was supported by Parmenides EIDOS tools suite offering several tools for analysis and scenarios building. The tool suite is used globally by public institutions in decision-making and strategic decisions, especially for complex processes requiring a multidisciplinary approach.

\subsubsection{Case study area Podpol'anie}

Case study area is located in the central part of Slovakia within Detva district. Podpolanie is traditional agricultural-forest region with specific cultural landscape development characterized by dispersed rural settlements and traditional land use (e.g. small private owners). Due to very favourable climatic conditions, Podpol'anie region is one of the most productive forest areas in Slovakia. Especially upper part covered by beech, fir-beech and spruce forests is very productive. Forest stands are relatively healthy and stable with predominance of original tree species composition, but there are also stands with artificially inserted spruce. State forest ownership dominates (almost 85\%), so State enterprise Forests of the SR is the strongest forestry entity in the CSA. From non-state subjects the biggest share has communal (8\%), private and church ownership (3\%), while the proportion of municipal forests is very small. The northern mountain area of the region dominated by the massif of Polana Mt. is part of the Carpathian Arc. Due to the richness of fauna and flora (nearly 2700 species), this part of CSA is under the Polana Protected Landscape Area. Moreover, more than half of territory (57\%) is covered by NATURA 2000 network. As the drink water reservoir Hriňová, located in CSA supplies drinking water to the surrounding cities, the water management function of the surrounding forest stands is equally important. Thanks to the Protected Game Area Polana, providing a coordinated ecological and large-scale management of the game, the region is known for its hunting tradition. The case study area is also intensively used for recreational activities such as hiking, mushroom picking, cycling as well as winter sports. For more information see also Navrátil et al. (2016) and Brodrechtová et al. (2018).

\subsubsection{Case study area Kysuce}

Case study area located in north-western Slovakia completely covers two districts - Čadca and Kysucké Nové Mesto. The rural population (56\%) prevails in the region, inhabiting 37 mostly rural municipalities. The region represents an agricultural and forest landscape forested by coniferous forests (84\%) mainly concentrated in the higher positions of the northern part of the territory. Almost half of the CSA belongs to the Kysuce Protected Landscape Area covering the northwest and northeast parts of the region. In the past the tree species composition in Kysuce has been significantly affected by the establishment of spruce monocultures. However, in the last decades the health of spruce forests in Kysuce has declined (e.g. Konôpka 2004; Kulla 2009) due to intensive and widespread necrosis (Hlásny et al. 2010; Bošela et al. 2014). This unfavourable situation causes frequent calamities, so the Kysuce belongs to the Slovak regions with highest volume of incidental felling (Vakula 2011). This situation mainly affects smaller non-state forest owners, as the forest ownership in Kysuce is highly fragmented with a large proportion of non-state owners (46\%). The largest share has the private ownership (33\%), followed by state (20\%) and communal (13\%). In addition, there is a large area of forests with unsettled ownership due to still ongoing restitution process (34\%). For more information see also Navrátil et al. (2016) and Brodrechtová et al. (2018).

\subsection{Characteristics of key factors and their variations}

Identification and selection of key factors for the selected CSAs were based on the results of studies done by Riemer et al. (2013), Navrátil et al. (2016) and Brodrechtová et al. (2018). Within these studies, a wide group of drivers and barriers of forest management have been created at first. From this group, the set of relevant factors were identified and finally, key factors were isolated for each CSA.

The drivers and barriers have been analysed at the local level of CSAs, as well as at the national and EU levels. Their identification was based on primary data (structured in-person interviews) and secondary data (output of qualitative analysis of national and European documents). Brodrechtová et al. (2018) identified via 50 in-person interviews with forest owners, managers and other relevant stakeholders from Podpolanie and Kysuce 22 drivers and barriers shaping forest management in 
the future from the local perspective. More precisely, biophysical conditions and attributes of the community, including the political and economic context, institutions, and discourses, were among the significant drivers affecting forest owners and managers, and their interactions and decisions concerning forest management in the Podpol'anie and Kysuce (Brodrechtová et al. 2018). Secondary data were analysed in the form of desktop research. An extensive review of existing national documents (e.g. strategic and prognostic documents related to forestry, rural economy and the nature protection) resulted in the isolation of subset of 28 drivers and barriers, including bio-physical conditions and attributes of the community, political and economic contexts, and institutions that can potentially determine decisions concerning forest management in Slovakia (national level) (Navrátil et al. 2016). In addition, an extensive review of existing national documents and $\mathrm{EU}$ documents resulted into the isolation of 35 drivers and barriers representing EU level (Riemer et al. 2013).

From the group of $85 \mathrm{local}$, national and EU drivers and barriers Navrátil et al. (2016) identified 20 relevant factors for each CSA. Reduction was completed within an expert workshop (10 experts from Technical University in Zvolen and National Forest Centre). From the list of 85 factors, every expert chose 20 factors considered the relevance for the further development of forest management in the CSAs and sorted all factors by importance. To facilitate the listing procedure the factors were structured according to STEEP analysis that provides a useful framework to assist experts in the consideration of factors external environment (Zanoli 2012). Finally, the factors were evaluated by the frequency analysis, taking into account the frequency and ranking of the factors. The set of 20 relevant factors for each CSA was subsequently grouped according to STEEP categories ('Society', 'Technology', 'Economy', 'Ecology' and 'Politics') (Navrátil et al. 2016).

For the purpose of scenarios creation, it was necessary to reduce number of relevant factors. Thus, the key factors were identified first, from which the final factors used to construct scenarios were selected. For the isolation of key factors, the method of structural analysis (Glenn and Gordon 2009) supported by Parmenides EIDOS were applied within participatory scenariobuilding workshops (forest owners, stakeholders from
CSAs, national level) conducted in each CSA. As result of the workshops a set of nine key factors crucial for the future forest management in Podpolanie and eight key factors in Kysuce were isolated (Navrátil et al. 2016).

Based on the results of the above studies and the key factors isolated, the research team chose final key factors used for designing the scenario space in each CSA. More detailed analysis of key factors, assessment of their individual character, similarity and the possibility of mutual aggregation resulted in selection of 8 final key factors in Podpolanie and 7 final key factors in Kysuce (Table 1). According to STEEP categories the policy, economic and ecological key factors prevailed within scenarios spaces in both CSAs. Based on the information collected during the previous phases of the research, a description of each factor was drawn up (Table A1, Table A2 in AppendixA).

The key factors were split into two groups by its nature: $\mathrm{G}$ - Given (factors considered as unchanged and stable in the future) and $\mathrm{U}$ - Uncertain (factors for which at least two possible future variations are suggested). Furthermore, for each factor the possible, plausible and alternative future variations for the next 30 years were created by research team. Three basic requirements were taken into account: (i) the future variations should integrate the results of the structural analysis and the available scientific information on the individual key factors, (ii) the future variations should be as plausible as possible, and (iii) the future variations should differ in a meaningful way. Total set of 20 possible future variations of factors for Podpol'anie and 18 variations for Kysuce has been created. Description and characteristics of created variations are provided in Appendix A of this paper (Table A3, Table A4).

\subsection{Design of morphological box}

\subsubsection{Weights and probability of occurrence}

Derived sets of key factors and their possible future variations represented individual dimensions of the future space of 30-years scenarios for Podpolanie and Kysuce. Morphological boxes were derived by the research team in Parmenides EIDOS. The morphological box for Podpolanie contained 8 factors and their 20 future variations (Fig. 1) while scenario's space matrix for Kysuce was represented by 7 factors and 18 variations (Fig. 2).

Table 1. Final key factors (with STEEP categories) selected for constructing of scenarios for Podpolanie and Kysuce.

\begin{tabular}{|c|c|c|c|c|c|c|c|}
\hline \multicolumn{8}{|c|}{8 factors in CSA Podpolanie: 7 uncertain factors U1-U7, 1 given factor G1 } \\
\hline $\begin{array}{c}\text { U1 } \\
\text { State of forests }\end{array}$ & $\begin{array}{c}\text { U2 } \\
\text { Policies and } \\
\text { legislation }\end{array}$ & $\begin{array}{c}\text { U3 } \\
\text { Timber/Bioenergy market }\end{array}$ & $\begin{array}{c}\text { U4 } \\
\text { Forest owner's } \\
\text { economic situation }\end{array}$ & $\begin{array}{c}\text { U5 } \\
\text { Non-wood ecosys- } \\
\text { tem services }\end{array}$ & $\begin{array}{c}\text { U6 } \\
\text { Innovation and } \\
\text { technology }\end{array}$ & $\begin{array}{c}\text { U7 } \\
\text { Codes of conduct }\end{array}$ & $\begin{array}{l}\text { G1 } \\
\text { Forest ownership }\end{array}$ \\
\hline Ecology & Policy & Economy & Economy & Ecology & Technology & Society & Policy \\
\hline \multicolumn{8}{|c|}{7 factors in CSA Kysuce: 7 uncertain factors U1-U7 } \\
\hline $\begin{array}{l}\text { U1 } \\
\text { State of } \\
\text { forests }\end{array}$ & $\begin{array}{c}\text { U2 } \\
\text { Forest ownership }\end{array}$ & $\begin{array}{c}\text { U3 } \\
\text { Subsidies }\end{array}$ & $\begin{array}{c}\text { U4 } \\
\text { Forest owner's } \\
\text { economic situation }\end{array}$ & $\begin{array}{c}\text { U5 } \\
\text { Timber market }\end{array}$ & $\begin{array}{c}\text { U6 } \\
\text { Innovation and } \\
\text { technology }\end{array}$ & U7 Population & \\
\hline Ecology & Policy & Policy & Economy & Economy & Technology & Society & \\
\hline
\end{tabular}


The significance of the individual factors for future forest management in CSAs was assessed by research team members via the weighting factors (numbers in the top row) and the probability of occurrence of each variation was expressed in percentage (numbers in lighter boxes). The significance of the individual key factor was expressed by assigning the appropriate weights to each factor with the sum of weights being 100 . The process was carried out in the framework of the discussion, using the expertise and knowledge base of the expert team, characteristics of factors and findings from previous research steps.

Each future factor's variation was associated with probabilities of its occurrence in the future, based on the assessment how probable a variation is compared to the other alternatives in the scenarios space. Within the discussion research team members answered the question: What is the probability that a given variation occurs over the next 30 years? Then the probability of its occurrence in percentage was attributed to each variation, while the sum of the percentages of all variations within the factor was $100 \%$. Due to its nature the given factor G1 - For- est ownership (in CSA Podpol'anie) was associated with a $100 \%$ probability, as it was assumed that the owner's structure would not change.

\subsubsection{Consistency matrix}

Within the created scenarios spaces the coherence of variations was assessed by defining relationships between the variations on the basis of internal consistency. The consistency was assessed by research team members during several brainstorming sessions with the support of Consistency Matrix tool of Parmenides EIDOS. The consistency matrix measures the logical fit of two variations. A higher consistency level indicates better coexistence of the two alternatives. A lower consistency rating indicates a greater degree of friction between the variations. Research team discussed and evaluated each variations pair by answering the questions: Do the two variations make sense together? How well or poorly do they fit together? The evaluation scale by Parmenides EIDOS was used (Table 2).

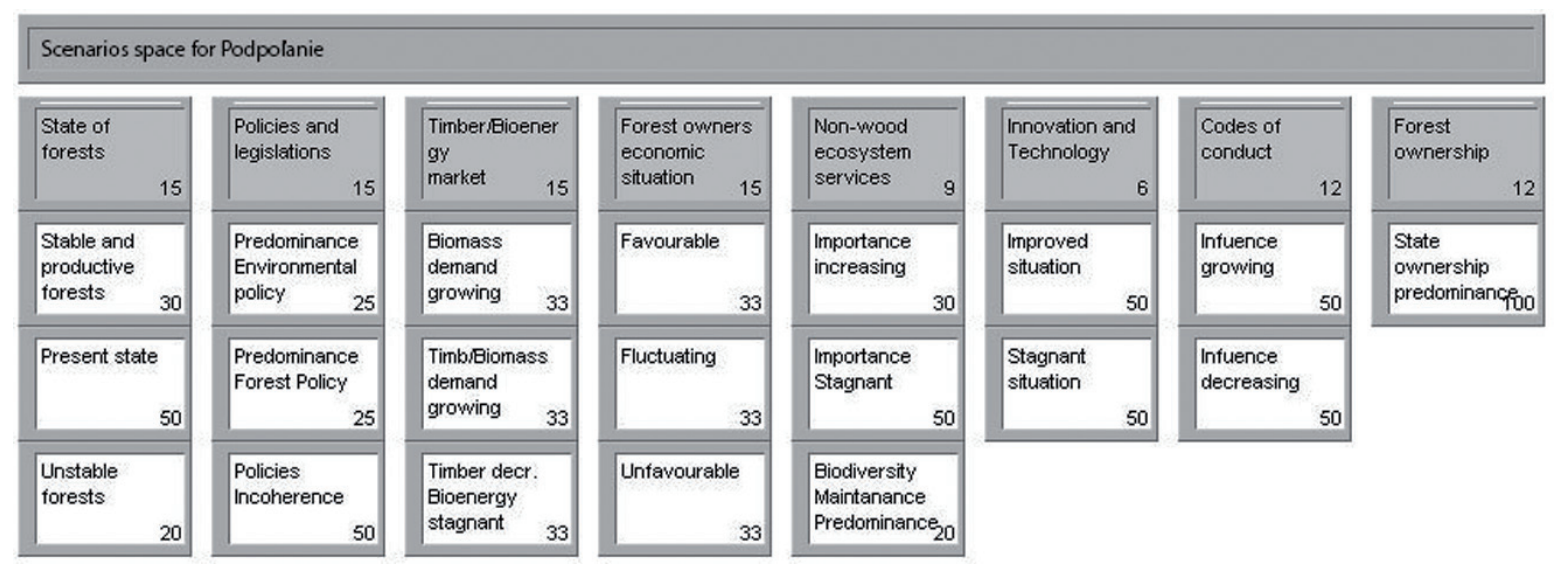

Fig. 1. Morphological box for Podpolanie.

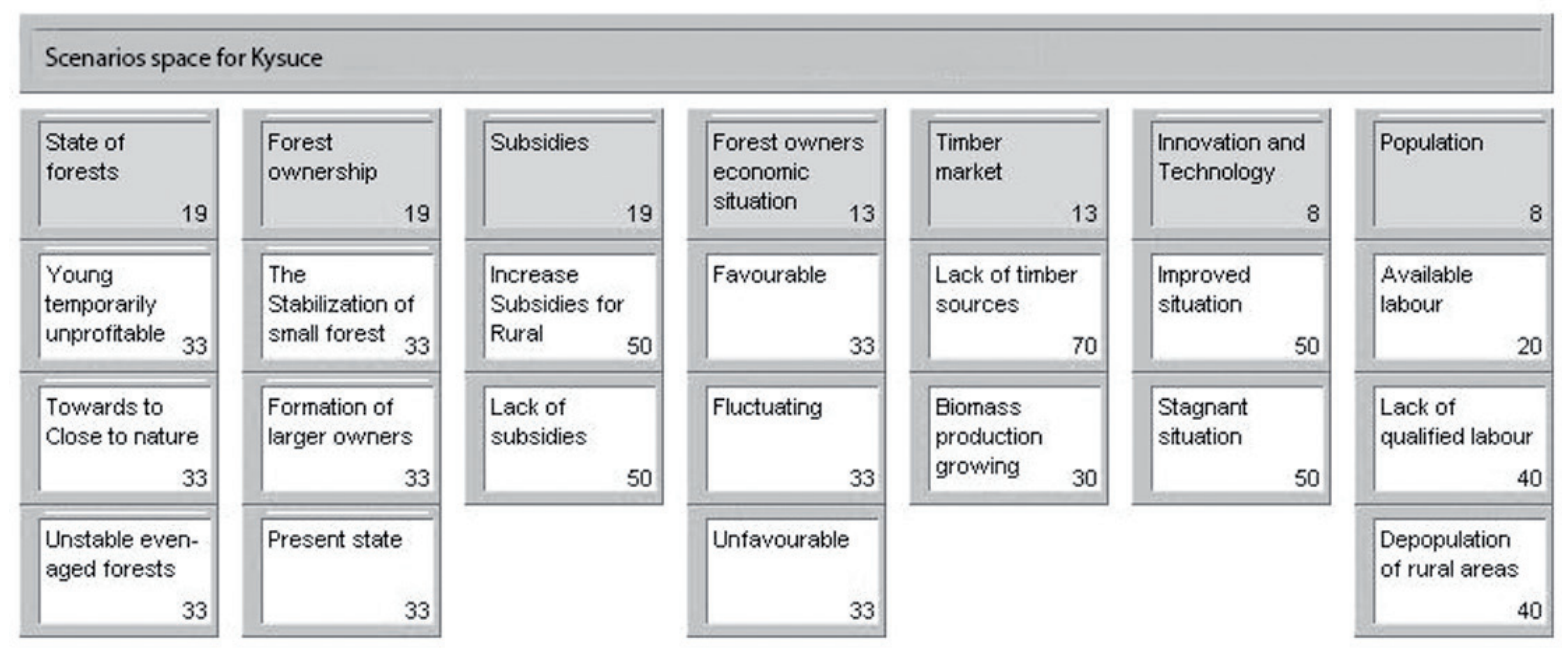

Fig. 2. Morphological box for Kysuce. 
Table 2. Consistency evaluation scale used for filling the consistency matrix.

-3 Complete inconsistency. Both projections exclude each other absolutely and cannot go together in a plausible scenario.

Strong partial inconsistency. Both projections strongly contradict each

-2 other. Their common appearance affects the credibility of a scenario strongly.

-1 Light partial inconsistency. Both projections contradict each other easily. Their common appearance lightly affects the credibility of a scenario. Neutrally or independently of each other. Both projections do not influence

0 each other and their common appearance does not influence the credibility of a scenario.

+1 Light mutual support. Both projections can coexist easily in a scenario.

+2 Strong mutual support. Both projections can go together rather well.

+3 Very strong mutual support. The common appearance of both projections +3 supports the strong credibility of the scenario.
The consistency values for each pair of variations were determined as a consensus after the discussion. In the case where was really difficult to assess relationships of the variations, the neutral dependency was assigned (value 0 ). The consistency for all combinations of variations was assessed by filling the matrices for both CSAs (Fig. 3, 4). The direction of impact does not have to be taken into consideration, thus it was sufficient to fill the area above the diagonal in the matrix. The consistency calculation was carried out by means of Parmenides EIDOS. The software calculates with a full enumeration all possible scenarios combinations with their internal consistencies. In consistency matrices in both CSAs, the

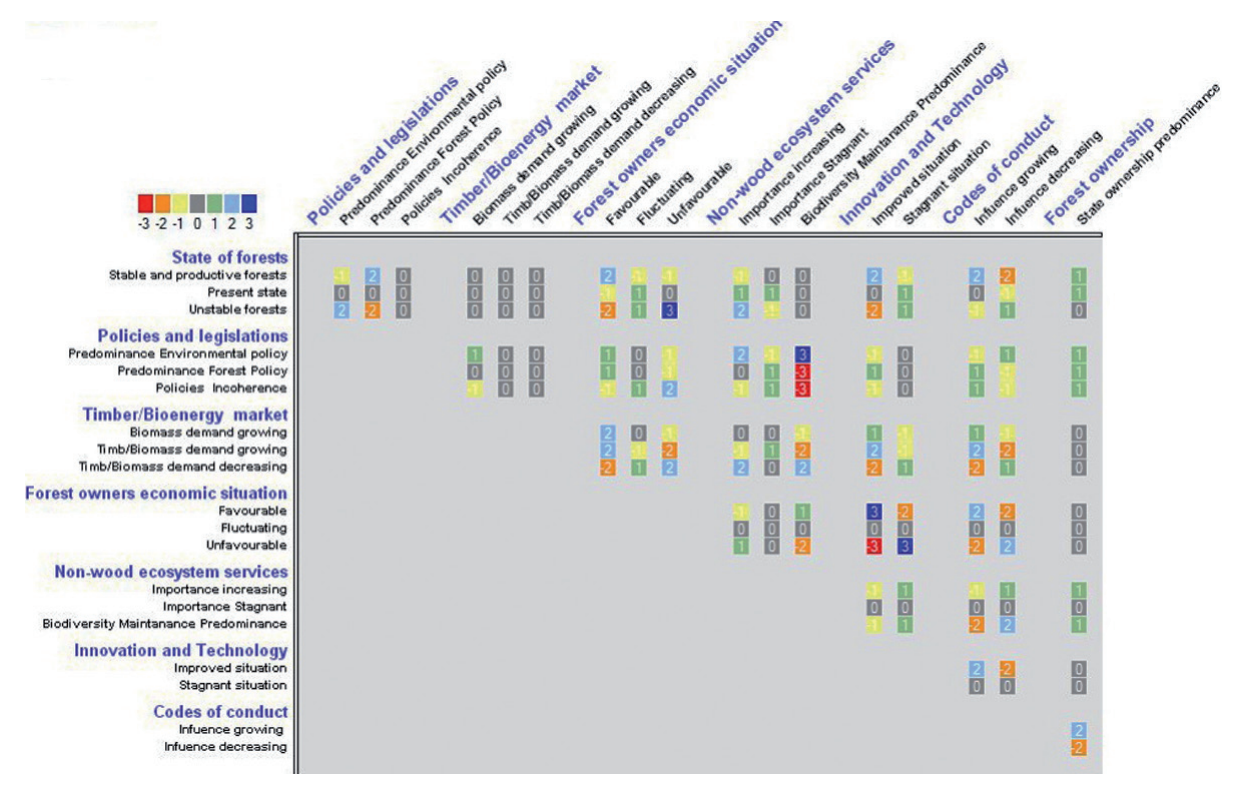

Fig. 3. Consistency matrix for Podpol'anie ( -3 complete inconsistency, +3 strong consistency).

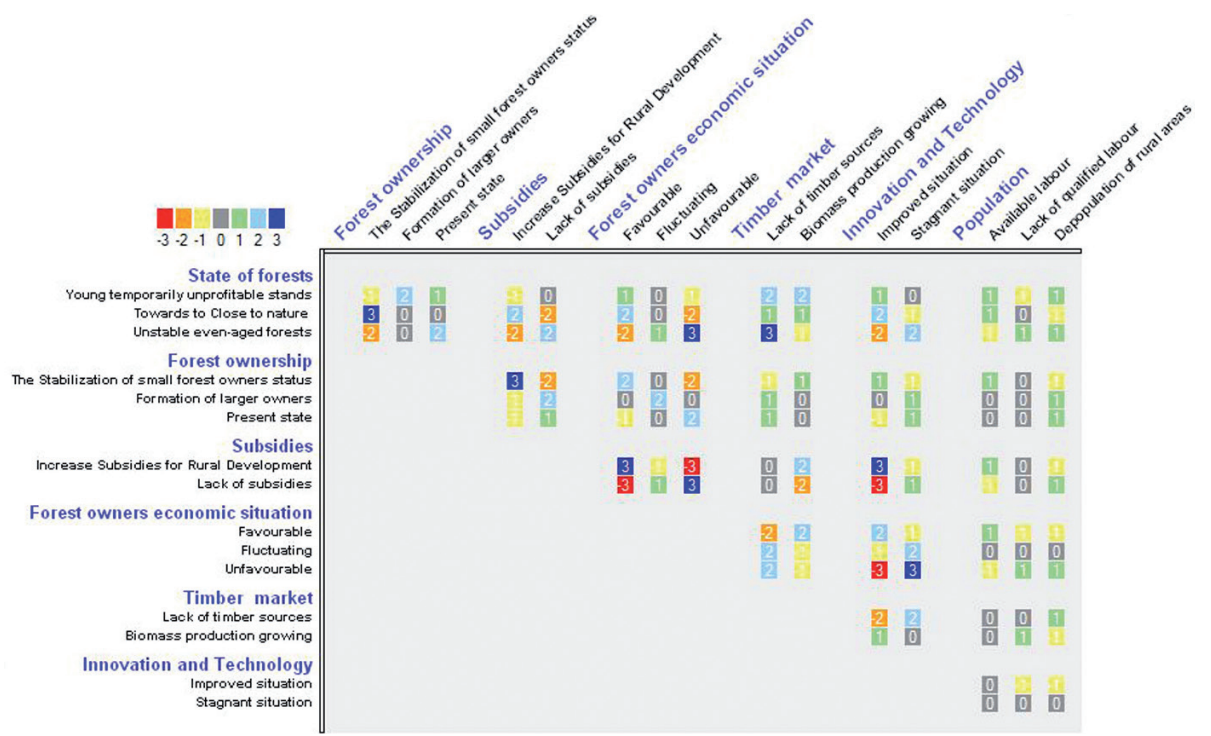

Fig. 4. Consistency matrix for Kysuce ( -3 complete inconsistency, +3 strong consistency). 
most commonly assigned consistency value was 0 (37\% in Podpolanie, 25\% in Kysuce), followed by +1 (20\% in Podpolanie, 22\% in Kysuce) and -1 (18\% in Podpolanie, $21 \%$ in Kysuce). The predominance of combinations 'neutrally or independently' (value 0) meant frequent occurrence of projections that do not affect each other but also the fact that it had often been difficult to assess the relationships of the variations.

\subsubsection{Cluster map}

Subsequently, clustering of coherent combinations of possible variations (scenarios) was carried out by Cluster Map tool of Parmenides EIDOS. The calculation was based on the number of factors and their assigned weights, a number of variations, their probabilities and consistency degrees assigned in consistency matrix. The cluster map displayed generated scenarios in two-dimen- sional distribution built up on their similarity and overall consistency. The cluster view is based on a complex projection algorithm and shows the 100 most consistent scenarios on a cluster map pooling single scenario (shown as circles) to clusters according to their similarity. The closer the circles that represent scenarios are, the more similar are the scenarios; the farther they are apart, the more different they are.

Internal consistency of scenarios is expressed by size of the circle in the map. The larger circle, the more internally consistent scenario and vice versa the small circle means a scenario with a small internal consistency. Calculation of overall degrees of consistency of individual scenarios was done by Parmenides EIDOS using scaled pairwise consistency assessment, where a weighting function assigns numerical values to the Likert-levels and the average of the consistency values of the involved tuples is calculated (Kempf 2015). Degrees of consistency (dimensionless numbers) represented overall

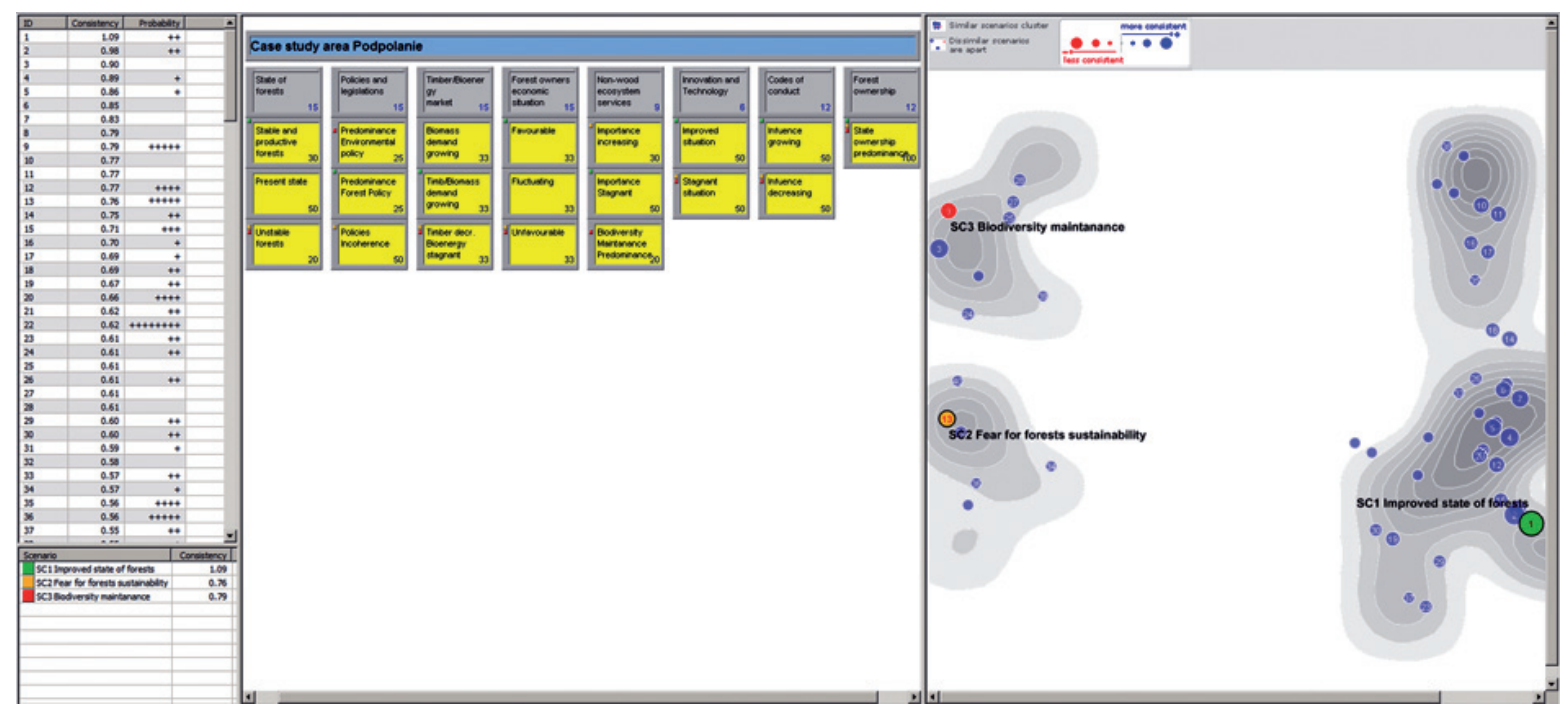

Fig. 5. Cluster map, morphological box, consistency degrees, probabilities and marked selected scenarios for Podpolanie.
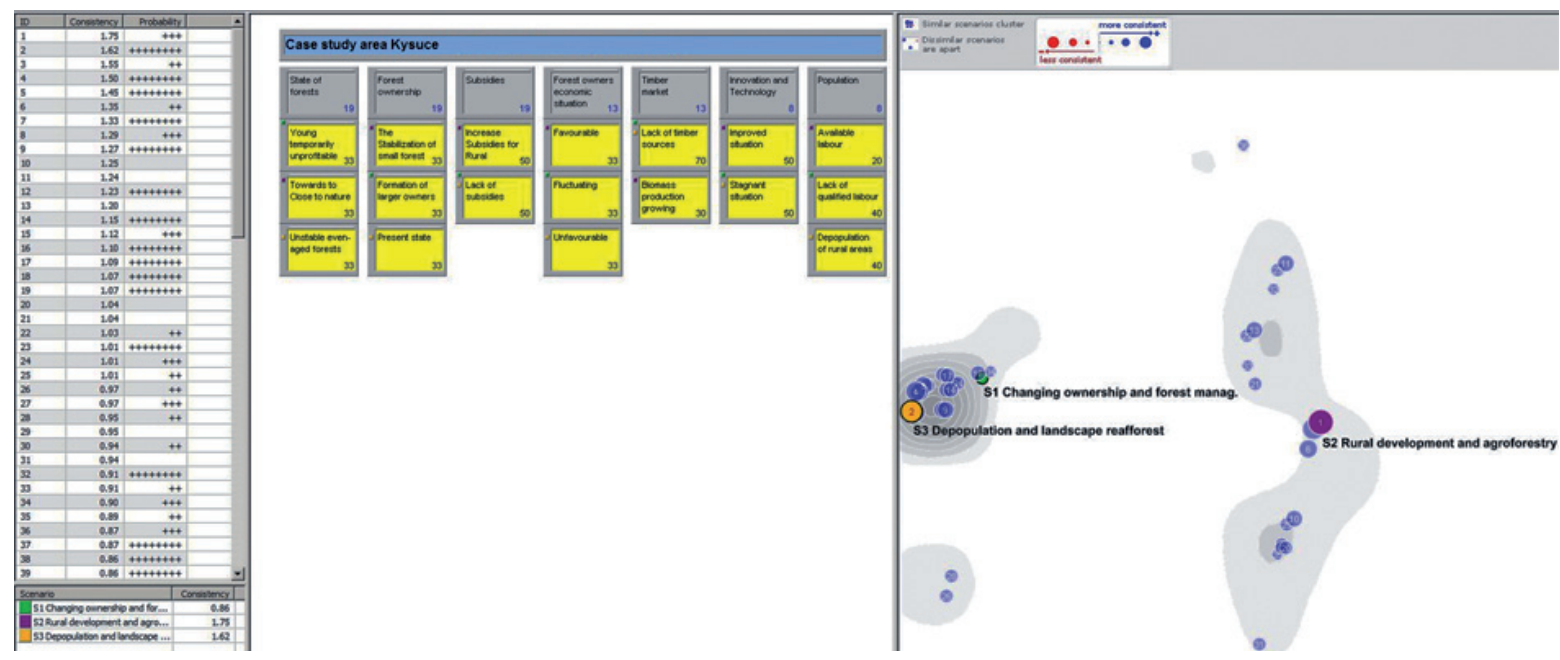

Fig. 6. Cluster map, morphological box, consistency degrees, probabilities and marked selected scenarios for Kysuce. 
internal consistency of individual scenarios and helped in selecting scenarios, since scenarios of greater consistency are of interest.

The probability of occurrence of the scenarios was carried out by Parmenides EIDOS using the probabilities of the individual variations defined in the morphological box. The scenario probability was expressed by the number of "+" marks associated with the scenario. A range of 0 (lowest probability) to 8 (highest probability) marks has been used.

From 8 factors and their 20 variations, a set of 972 possible future scenarios have been derived for Podpolanie. It can be clearly identified in the cluster map (Fig. 5) that all possible scenarios are redistributed into four main groups of clusters. Scenarios concentrated close together in a cluster were meaningfully similar to each other. Since the goal was to select mutually different scenarios, the focus was mainly on different groups of clusters. A ranking procedure by degrees of consistency was applied to identify scenarios which are particularly consistent. Calculated consistency degrees of scenarios ranged from 0.1 (lowest consistency) to 1.09 (highest consistency). Most of the 972 scenarios had a low degree of consistency, with only 65 had the consistency degree greater than 0.5 .

In Kysuce, a combination of 7 elements and their 18 manifestations, resulted in a set of 648 possible future scenarios (Fig. 6). At least five main groups of clusters could be identified in the map. Probabilities of occurrence, as well as consistency degrees, reached higher values compared to Podpolanie. The consistency ranged in 0.2 to 1.75 and 25 scenarios had consistency degree greater than 1.0.

\subsubsection{Selection of final forest management scenarios}

The final selection of scenarios for both CSAs was done by the research team during several brainstorming sessions. As the result, the three scenarios of possible future development of forest management in Podpolanie and Kysuce regions were selected (Table 3, 4). The process was supported by Parmenides EIDOS but the decision was reached by a consensus of team members. The choice of scenarios was determined by three criteria: consistency, diversity and plausibility. Cluster maps displaying the scenarios in a cluster view were used to ease the selection. To avoid selecting several scenarios that are simply slight variations on the same theme, distinct clusters were identified at first. This has ensured the diversity criterion to select scenarios each other meaningfully distinguished. Then we looked for the most consistent scenarios in the cluster. The more consistent scenarios were, the bigger they were displayed in the cluster map. The ranking by consistency degrees showed scenarios with the high consistency, but the order itself was not a decisive criterion because it does not take into account diversity of scenarios. That's why the combination of cluster map visualisation and consistency degrees was used for the selection. To obtain reasonably likely scenarios the probability of their occurrence over the next 30 years was considered. Scenarios marked with 0 or 1 "+" were excluded from the selection. We have focused particularly on scenarios with 4 and more "+". But, as can be seen (Table 3,4 ) the most consistent scenarios in both CSAs had a probability of only 2 “+” or 3 “+” respectively. Considering the highest consistency and focus of these scenarios, the lower probability was accepted by the research team. This shows that despite strong software support, the final decision was on the research team that took into account all the information gathered during the all research phases.

\section{Features of selected forest management scenarios}

As a result of the morphological analysis process, three selected scenarios of possible future development of forest management were identified for each CSA. These scenarios meet the requirement of internal consistency, are meaningful, probable and mutually different. Each scenario was created by combining selected variations that define the scenario itself (Table 5, 6). For scenarios, the brief basic descriptive features that are presented in this chapter have been created.

Table 3. Selected scenarios for Podpol'anie.

\begin{tabular}{|c|c|c|c|}
\hline Name of scenario & Consistency degree & $\begin{array}{l}\text { Order by consistency } \\
\text { (from } 972 \text { scenarios) }\end{array}$ & $\begin{array}{c}\text { Probability of occur- } \\
\text { rence }\end{array}$ \\
\hline Scenario 1: Improved state of forests and increased wood demand & 1.09 & 1. & ++ \\
\hline Scenario 2: Fear for forest sustainability & 0.76 & 13. & +++++ \\
\hline Scenario 3: Biodiversity maintenance - Growing societal demand for nature conservation & 0.79 & 9. & +++++ \\
\hline
\end{tabular}

Table 4. Selected scenarios for Kysuce

\begin{tabular}{|c|c|c|c|}
\hline Name of scenario & Consistency degree & $\begin{array}{l}\text { Order by consistency } \\
\text { (from } 648 \text { scenarios) }\end{array}$ & $\begin{array}{l}\text { Probability of occur- } \\
\text { rence }\end{array}$ \\
\hline Scenario 1: Transformation of ownership and change of the forest management objectives & 0.86 & 38 & ++++++++ \\
\hline Scenario 2: Rural development and agro-forestry landscape use & 1.75 & 1. & +++ \\
\hline Scenario 3: Depopulation and landscape afforestation & 1.62 & 2. & ++++++++ \\
\hline
\end{tabular}




\subsection{Selected scenarios for CSA Podpolanie}

Table 5. Final scenarios for Podpolanie - selected combinations of future variations of key factors.

\begin{tabular}{|c|c|c|c|c|c|c|c|c|}
\hline Scenarios & $\begin{array}{c}\text { U1 } \\
\text { State of forests }\end{array}$ & $\begin{array}{c}\mathrm{U} 2 \\
\text { Policies and } \\
\text { legislation }\end{array}$ & $\begin{array}{c}\text { U3 } \\
\text { Timber/Bioenergy } \\
\text { market }\end{array}$ & $\begin{array}{c}\mathrm{U} 4 \\
\text { Forest owner's } \\
\text { economic } \\
\text { situation } \\
\end{array}$ & $\begin{array}{c}\text { U5 } \\
\text { Non-wood } \\
\text { ecosystem services }\end{array}$ & $\begin{array}{c}\text { U6 } \\
\text { Innovation and } \\
\text { technology }\end{array}$ & $\begin{array}{c}\text { U7 } \\
\text { Codes of conduct }\end{array}$ & $\begin{array}{l}\text { G1 } \\
\text { Forest ownership }\end{array}$ \\
\hline Sc. 1 . & $\begin{array}{c}\text { U1a } \\
\text { Stable and } \\
\text { productive forests }\end{array}$ & $\begin{array}{c}\mathrm{U} 2 \mathrm{~b} \\
\text { Predominance } \\
\text { forest policy } \\
\end{array}$ & $\begin{array}{c}\text { U3b } \\
\text { Timber/Bioenergy } \\
\text { demand growing } \\
\end{array}$ & $\begin{array}{c}\text { U4a } \\
\text { Favourable }\end{array}$ & $\begin{array}{c}\text { U5b } \\
\text { Importance } \\
\text { Stagnant } \\
\end{array}$ & $\begin{array}{c}\text { U6a } \\
\text { Improved } \\
\text { situation } \\
\end{array}$ & $\begin{array}{c}\text { U7a } \\
\text { Influence growing }\end{array}$ & $\begin{array}{c}\text { G1a } \\
\text { State ownership } \\
\text { predominance }\end{array}$ \\
\hline Sc. 2 . & $\begin{array}{c}\text { U1c } \\
\text { Unstable forests }\end{array}$ & $\begin{array}{c}\text { U2c } \\
\text { Policies } \\
\text { incoherence }\end{array}$ & $\begin{array}{c}\text { U3c } \\
\text { Timber decreasing } \\
\text { Bioenergy } \\
\text { stagnant } \\
\end{array}$ & $\begin{array}{c}\text { U4c } \\
\text { Unfavourable }\end{array}$ & $\begin{array}{c}\text { U5a } \\
\text { Importance } \\
\text { increasing }\end{array}$ & $\begin{array}{c}\text { U6b } \\
\text { Stagnant situation }\end{array}$ & $\begin{array}{c}\text { U7b } \\
\text { Influence } \\
\text { decreasing }\end{array}$ & $\begin{array}{c}\text { G1a } \\
\text { State ownership } \\
\text { predominance }\end{array}$ \\
\hline Sc. 3 . & $\begin{array}{c}\text { U1c } \\
\text { Unstable forests }\end{array}$ & $\begin{array}{c}\mathrm{U} 2 \mathrm{a} \\
\text { Predominance } \\
\text { environmental } \\
\text { policy }\end{array}$ & $\begin{array}{c}\text { U3c } \\
\text { Timber decreasing } \\
\text { Bioenergy } \\
\text { stagnant }\end{array}$ & $\begin{array}{c}\text { U4c } \\
\text { Unfavourable }\end{array}$ & $\begin{array}{c}\text { U5c } \\
\text { Dominance } \\
\text { of biodiversity } \\
\text { maintenance }\end{array}$ & $\begin{array}{c}\text { U6b } \\
\text { Stagnant situation }\end{array}$ & $\begin{array}{c}\text { U7b } \\
\text { Influence } \\
\text { decreasing }\end{array}$ & $\begin{array}{c}\text { G1a } \\
\text { State ownership } \\
\text { predominance }\end{array}$ \\
\hline
\end{tabular}

Table 6. Final scenarios for Kysuce - selected combinations of future variations of key factors.

\begin{tabular}{|c|c|c|c|c|c|c|c|}
\hline $\begin{array}{l}\text { Factors } \\
\text { Scenarios }\end{array}$ & $\begin{array}{c}\text { U1 } \\
\text { State of forests }\end{array}$ & $\begin{array}{c}\text { U2 } \\
\text { Forest ownership }\end{array}$ & $\begin{array}{c}\text { U3 } \\
\text { Subsidies }\end{array}$ & $\begin{array}{c}\text { U4 } \\
\text { Forest owner's } \\
\text { economic situation }\end{array}$ & $\begin{array}{c}\text { U5 } \\
\text { Timber market }\end{array}$ & $\begin{array}{c}\mathrm{U} 6 \\
\text { Innovation and } \\
\text { technology }\end{array}$ & $\begin{array}{c}\text { U7 } \\
\text { Population }\end{array}$ \\
\hline Sc. 1. & $\begin{array}{c}\text { U1a } \\
\text { Young temporarily } \\
\text { unprofitable stands }\end{array}$ & $\begin{array}{c}\text { U2b } \\
\text { Formation of larger } \\
\text { owners }\end{array}$ & $\begin{array}{c}\text { U3b } \\
\text { Lack of subsidies }\end{array}$ & $\begin{array}{c}\text { U4b } \\
\text { Fluctuating }\end{array}$ & $\begin{array}{c}\text { U5a } \\
\text { Lack of timber } \\
\text { sources }\end{array}$ & $\begin{array}{c}\text { U6b } \\
\text { Stagnant situation }\end{array}$ & $\begin{array}{c}\text { U7b } \\
\text { Lack of qualified } \\
\text { labour }\end{array}$ \\
\hline Sc. 2. & $\begin{array}{c}\text { U1b } \\
\text { Towards to } \\
\text { Close to nature }\end{array}$ & $\begin{array}{l}\text { U2a } \\
\text { Stabilisation of small } \\
\text { forest owner's status }\end{array}$ & $\begin{array}{c}\text { U3a } \\
\text { Increased subsidies } \\
\text { for rural development }\end{array}$ & $\begin{array}{c}\text { U4a } \\
\text { Favourable }\end{array}$ & $\begin{array}{c}\text { U5b } \\
\text { Biomass production } \\
\text { growing }\end{array}$ & $\begin{array}{c}\text { U6a } \\
\text { Improved situation }\end{array}$ & $\begin{array}{c}\text { U7a } \\
\text { Available labour }\end{array}$ \\
\hline Sc. 3. & $\begin{array}{c}\text { U1c } \\
\text { Unstable even-aged } \\
\text { forests }\end{array}$ & $\begin{array}{c}\mathrm{U} 2 \mathrm{c} \\
\text { Present state }\end{array}$ & $\begin{array}{c}\text { U3b } \\
\text { Lack of subsidies }\end{array}$ & $\begin{array}{c}\text { U4c } \\
\text { Unfavourable }\end{array}$ & $\begin{array}{c}\text { U5a } \\
\text { Lack of timber } \\
\text { sources }\end{array}$ & $\begin{array}{c}\text { U6b } \\
\text { Stagnant situation }\end{array}$ & $\begin{array}{c}\text { U7c } \\
\begin{array}{c}\text { Depopulation of } \\
\text { rural areas }\end{array} \\
\end{array}$ \\
\hline
\end{tabular}

Scenario 1: Improved state of forests and increased wood demand

Full use of the natural production potential of forests in Podpolanie is predicted. Such maximal utilization will also be supported by the application of short-term rotation forestry under preservation of the sustainability and ecological stability of forests with less emphasis on the provision of other ecosystem services. Lessening the impact of climate change and ecological disturbance is awaited. Health conditions and ecological stability of forests will stay on the current level, respectively will be improved. Strong political enforcement of the economic interests of forest owners over the interests of nature conservation is expected. Despite a harmonization of environmental and forestry policies, the forest law will be more strongly enforced as a law on nature conservation. Growing wood demand is estimated due to new investments in timber processing capacities and/or due to increased support of energy from renewable resources, particularly from biomass. Lower societal demands for the fulfilment of other ecosystem services are expected. It will lead to a reduction in the extent of forest protection and biodiversity conservation.

\section{Scenario 2: Fear for forest sustainability}

Applying measures to systematically enhance the sustainability and ecological stability of forest stands in Podpol'anie is expected. The measures will be applied in combination with strengthening the provision of selected non-production ecosystem services (water, recreation, hunting, research function), which will be complemented by secondary wood and biomass production. Increasing the negative impact of climate change and ecological disturbances on forest stands are anticipated. Effective forest management, mainly focused on the production function, in practice will not be possible or will be significantly limited. Increased efforts by forest owners for income outside the forest are foreseen. The incoherence of forestry and environmental policy will persist, but as a result of social pressures, the importance of sustainable management is expected to increase, which, on the other hand, will enhance the protection of nature and biodiversity.

\section{Scenario 3: Biodiversity maintenance - Growing societal demand for nature conservation}

The dominance of nature and biodiversity protection, expanding the provision of certain non-production ecosystem services (recreation, water, research) is foreseen in Podpolanie. Passive forest management is expected, coupled with strong restrictions on any active interventions (minimizing the provision of production functions and hunting). The strong demand and interest of society will lead to the strengthening of nature conservation legislation in favour of the economic interests of existing forest owners. Misunderstandings between foresters and 
environmentalists in the region will be resolved in favour of the environmentalists. The state will either completely purchase forest land from small owners or will be willing to pay full compensation for the restriction of forest management.

\subsection{Selected scenarios for CSA Kysuce}

\section{Scenario 1: Transformation of ownership and change of the forest management objectives}

In the 30-year time horizon, the existence of large areas of even-aged mixed coppices formed naturally is expected as a result of the predicted collapse of large complexes of unnatural spruce stands in Kysuce. Ecological stability of dense and even-aged forest stands may not be fully satisfactory due to the increasing cost of stands tending. At the same time, the revenues from timber production will be significantly reduced due to the unfavourable situation in the domestic and foreign markets. It is assumed that small private forest owners will sell their land to bigger investors because the income from the forests will be significantly lower and no more subsidies are expected to be provided. In addition, due to rising forest management costs of forest land of unknown owners as well as due to growing political and social pressure, the state will be forced to address the issue of forest land of unknown owners. The same or rising demand for pulp and new biomass requirements for energy purposes are foreseen.

\section{Scenario 2: Rural development and agroforestry landscape use}

Expansion of the rural development policy, supported by a sufficient amount of subsidies is expected in Kysuce. It is supposed that this will lead to the preservation of the fragmented forestry agrarian landscape. The number of subsidies will be sufficient for the preservation and development of agricultural activities, as well as on developing the use of biomass in the forest sector. The fragmented nature of the land ownership will be preserved, because of forest owners regardless of the situation on in timber and biomass trade, will be financially motivated to maintain the current forestry agrarian character of the landscape. It is expected the adoption of new legislation promoting the production of biomass and forest management. Biomass from increased production areas will be effectively exploited the growing bioenergy sector. Furthermore, these processes supported by subsidies will lead to job creation and to meeting the demands for skilled labour.

\section{Scenario 3: Depopulation and landscape afforestation}

Lack of subsidies and limited timber production will further increase the depopulation of the Kysuce and cause a massive reduction in non-economic agrarian and forestry activities. Extending the successive development of ecosystems on abandoned agricultural land and self-devel- opment of forest stands is envisaged. Lack of resources for forest management, low income from timber and biomass production as well as lack of subsidies will lead to a fall in investment and job losses. Big investors will not be interested in buying forest land of small owners due to rising costs for tending of naturally regenerated even-aged mixed forest stands, lack of qualified labour and need for technological innovation. This will result in the conversion of fragmented forestry agrarian landscape to large complexes of fields, meadows and pastures overgrown with pioneer tree species. Due to high management costs, lack of subsidies and poor sales, the necessary tending of forest stands will also be neglected. The stability and health status of forest stands will further deteriorate. A shift towards close to nature management will also be problematic because such a transformation of forests requires time and investment in the necessary technology.

\section{Discussion and conclusions}

The future forest management could be driven by many factors and their variations, yet their combinations would deliver many scenarios. The morphological analysis offers systematic approach and helps to deal with the complexity that consists of a set of relationships, multidimensional and non-quantifiable problems challenging forest management. In this study, we have shown its applicability in forest management scenario modelling with an example taken from forest management in two traditional agricultural-forest Slovak regions. This specific qualitative approach of prognostic method of future scenarios was used for the prediction of forest management development probably for the first time in the conditions of the Slovak forestry.

In the paper, the created scenarios are presented in the form of a brief description of the situation that can occur in 30 years. These scenarios can serve as a driving scenarios for further steps toward the final decision scenarios. Schoemaker (1995) called these scenarios Learning scenarios that help outline the boundaries of further development and identify themes that are strategically relevant in each case study area. They become the basis for further research to organize the possible outcomes and trends around these themes. While the Podpolanie region was particularly concerned with the possible implementation of the forestry or nature conservation paradigms, the scenarios in the Kysuce region were mainly concerned with the topic of the ownership structure and its impact on forest ecosystems.

As learning scenarios are results of qualitative approach, the further research could be focused on quantitative models' implementation or evaluation of stakeholder's behaviours in given scenarios. By implementing forestry Decision Support Systems or growth simulators e.g. Silva (Pretzsch et al. 2002), Sibyla (Fabrika 2007), 
Heureka (Heureka 2010) or Optimal (Marušák 2015) to the trends set in the individual scenarios, it is possible, for example, to quantify the fulfilment of ecosystem services in forest ecosystems in each region. The modelling can include simulated behaviour of forest owners and stakeholders, and various forest management measures correlating with the theme of the scenarios. The quantification of the consequences of various scenarios significantly enhances the credibility of the scenarios and allows them to be further extended as narrative scenarios into stories. Such scenarios can be further used in decision-making processes, for example, using the backcasting method (Wilson et al. 2006) exploring the feasibility of desirable futures set in scenarios.

Implementation of the whole scenario modelling process has been a challenge for the research team. Our experience has shown that the method cannot be realized by an individual, but the process requires experienced team capable of assessing socio-economic, technological and environmental or policy aspects of forestry issues. The steps of scenarios' consistency and credibility assessment were carried out in a number of iterations, using the brainstorming, discussion and consensus. Evans et al. (2008) called this process as a mental exercises to consider plausible, future situations, imagine potential outcomes and explore contingencies. Parmenides EIDOS toll suite was very helpful throughout the modelling process. The software provided flexible tools for scenario's spaces management and visualisation that facilitated and clarified the whole process. However, like suggested by Gausemeier et al. (2009) the choice of final scenarios was supported by software, but not determined by it.

In the study, we used the participatory approach in particular in the initial phases of modelling scenarios; inperson interviews and structural analysis involving forest owners and stakeholders helped to isolate the crucial factors that later became the basis for scenarios. Based on our findings, it is advisable to involve forest owners and other stakeholders also in the process of consistency assessment itself. The process could be done by adding another participatory workshop where participants would jointly assess the morphological box, fill out the consistency matrix and judge the created set of scenarios. Stakeholders would discuss and evaluate the consistency of each variation pair. Weccard (2012) suggested to display on a screen two newspapers with a different top headline, that are the names of a variations from the variation pair and ask participants How do the two headlines make sense together? By using attractive visualization tools of Parmenides EIDOS, stakeholders could discuss and identify their preferred scenarios or scenarios they would like to avoid. Through joint consensus, they would be involved in planning the future direction of forest management in their region. The selection of workshop participants is crucial in order to achieve relevant results. It is important to involve relevant decision makers, experienced and informed owners and stakeholders with the relation to the region representing all relevant stakeholder groups. Engaging the same stakeholders as in earlier steps of the scenario making process can guarantee their interest in issues of forest management in their region. Beside this, the whole research team mustalso be involved in this kind of workshop, with the facilitator's role in managing the productive discussion very important.

Our experience demonstrated that the morphological analysis supported by Parmenides EIDOS is a useful method for forest management modelling challenged by many factors (e.g., forest policy, forest owner's behaviour) that by their nature are not applicable for analysis via deterministic or probabilistic methods (e.g. Ritchey 2011, 2015). As scenario studies concerning forest management have rather quantitative, non-participatory, or single factor in nature character (Hoogstra et al. 2017), an application of qualitative future scenarios method enriched by a quantitative model can introduce the use of the mixed-methods and participation into forest management scenarios modelling in Slovakia. Such forest management scenarios modelling carried out in a participatory manner may be considered a means to improve collaboration and promote dialogue among forest owners, other forestry stakeholders and the general public as well. Additionally, participatory scenario modelling workshops might increase the stakeholders' interest in engaging in forest management planning processes, as this method is systematic, interesting and productive.

\section{Acknowledgements}

This research study has received funding from the EU's Seventh Programme for research, technological development and demonstration under grant agreement No. 282887.

\section{References}

Albert, M., Hansen, J., Nagel, J., Schmidt, M., Spellmann, H., 2015: Assessing risks and uncertainties in forest dynamics under different management scenarios and climate change. Forest Ecosystems, 2:14.

Amer, M., Daim, T. U., Jetter, A., 2013: A review of scenario planning. Future, 46: 23-40.

Bishop, P., Hines, A., Collins, T., 2007: The current state of scenario development: an overview of techniques. Foresight, 9:5-25.

Bošela, M., Sedmák, R., Sedmáková, D., Marušák R., Kulla, L., 2014: Temporal shifts of climate-growth relationships of Norway spruce as an indicator of health decline in the Beskids, Slovakia. Forest Ecology and Management, 325:108-117.

Brodrechtová, Y., Navrátil, R., Sedmák, R., Tuček, J., 2018: Using the politicized IAD framework to assess integrated forest management decision making in Slovakia. Land Use Policy, 79:1001-1013. 
Carlsson, J., Eriksson, L. O., Öhman, K., Nordström, E. M., 2015: Combining scientific and stakeholder knowledge in future scenario development - a forest landscape case study in northern Sweden. Forest Policy and Economics, 61:122-134.

Dilek, C., 2009: The Scenario Analysis Tool Suite: A User's Guide. Joint Operations Division Defence Science and Technology Organisation Canberra, 24 p.

Eriksson, T., Ritchey, T., 2002: Scenario Development using Computerised Morphological Analysis. Swedish Defence Research Agency Stockholm, 8 p.

Evans, K., Cronkleton, P., de Jong, Wil., 2008: Future Scenarios as a Tool for Collaboration in Forest Communities. Sapiens. 1. 10.5194/sapiens-1-97-2008.

Fabrika, M., 2007: Implementation of GIS and model SIBYLA in a special decision support system for forest management. In: Kappas, M., Kleinn, C., Sloboda, B. (eds.), 2007: Global Change Issues in Developing and Emerging Countries, Proceedings of the second Göttingen GIS and Remote Sensing Days. Göttingen, Germany, Universitaetsverlag Göttingen, p. 61-72.

Gaßner, R., Steinmüller, K., 2004: Scenarios that tell a story; Normative Narrative Scenarios - An efficient tool for participatory innovation-oriented foresight. In: Proceedings of the EU-US Scientific Seminar: New Technology Foresight, Forecasting \& Assessment Methods in Seville, Spain, p. 31-37.

Gausemeier, J., Plass, C., Wenzelmann, C., 2009: Zukunftsorientierte Unternehmensgestaltung: Strategien, Geschäftsprozesse und IT-Systeme für die Produktion von morgen. München, Hanser, p. 404-405.

Glenn, J. C., Gordon, T. J. (eds.), 2009: The Millennium Project: Futures Research Methodology. Version 3.0. (CD-ROM).

Godet, M., Roubelat, F., 1996: Creating the future: The use and misuse of scenarios. Long Range Planning, 29:164-171.

Greeuw, S. C. H., van Asselt, M. B. A., Grosskurth, J., Storms, Ch.A. M. H., Rijkens-Klomp, N., Rothman, D. S., Rotmans, J., 2000: Cloudy Crystal Balls: An assessment of recent European and global scenario studies and models, European Environment Agency, $113 \mathrm{p}$.

Heinecke, A., 2006: Die Anwendung induktiver Verfahren in der Szenario-Technik. In: Falko E. P. Wilms (ed.), Szenariotechnik: Vom Umgang mit der Zukunft, Bern, Haupt Verlag, p. 183-213.

Hengeveld, G. M., Schüll, E., Trubins, R., Sallnäs, O., 2017: Forest Landscape Development Scenarios (FoLDS) - a framework for integrating forest models, owners' behaviour and socio-economic developments. Forest policy and economics. 85:245-255.

Hlásny, T., Sitková, Z. (eds.), 2010: Spruce forests decline in the Beskids. National Forest Centre-Forest Research Institute Zvolen \& Czech University of Life Sciences Prague \& Forestry and Game Management Research Institute Jíloviště - Strnady, 184 p.
Hoogstra-Klein, M. A., Hengeveld, G. M., de Jong, R., 2017: Analysing scenario approaches for forest management-One decade of experiences in Europe. Forest Policy and Economics, Elsevier, 85:222-234.

Johansen, I., 2018: Scenario modelling with morphological analysis. Technological Forecasting and Social Change, 126:116-125.

Kempf, J., 2015:Visualizing general morphological analysis via multidimensional scaling. Bachelor Thesis, University of Passau, 89 p.

Konôpka, J., 2004: Hynutie lesov, najmä smrečín na Slovensku v druhej polovici 20. storočia a opatrenia na zlepšenie situácie. In: Zúbrik, M. (ed.): Hynutie lesov, najmä smrečín na Slovensku v druhej polovici 20. storočia a opatrenia na zlepšenie situácie.Zvolen, NLC, 52 p.

Korosuo, A., Sandström, P., Öhman, K., Eriksson, L. O., 2014: Impacts of different forest management scenarios on forestry and reindeer husbandry. Scandinavian Journal of Forest Research, 29:234-251.

Kovalčík, M., Sarvašová,Z., Schwarz, M., Moravčík, M., Oravec, M., Lásková, J., Tutka, J., 2012: Financial and socio-economic impacts of nature conservation on forestry in Slovakia. Journal of Forest Science, 58:425-435.

Kulla, L., Merganič, J., Marušák, R., 2009: Analysis of natural regeneration in declining spruce forests on the Slovak part of the Beskydy Mts. Beskydy, 2:51-62.

Marušák, R., Kašpar, J., Vopěnka, P., 2015: Decision Support Systems (DSS) Optimal-ACase Study from the Czech Republic. Forests, 6:163-182.

Navrátil, R., Brodrechtová, Y., Sedmák, R., Smreček, R., Tuček, J., 2016: Structural analysis of the drivers and barriers of forest management in the Slovak regions of Podpol'anie and Kysuce. Forestry Journal, 62:152-163.

Nordström, E. M., Holmström, H. and Öhman, K., 2013: Evaluating continuous cover forestry based on the forest owner's objectives by combining scenario analysis and multiple criteria decision analysis. Silva Fennica, 47:22.

Pillkahn, U., 2008: Using Trends and Scenarios as Tools for Strategy Development: Shaping the Future of Your Enterprise. Erlangen, Publicis Corporate Publishing, $452 \mathrm{p}$.

Pretzsch, H., Biber, P., Durský, J., 2002: The single treebased stand simulator SILVA: construction, application and evaluation. Forest Ecology and Management, 162:3-21.

Riemer, A., Betuch, H., Zhirkova, I., Winkler, J., Wappler, S., Storch, S., 2013: Impact of selected structural factors on the forest-based sector in the European Union, Fraunhofer MOEZ, Leipzig, 61 p.

Ritchey, T., 2009: Morphological Analysis. Futures Research Methodology 3.0 (CD-ROM). 
Ritchey, T., 2011: Wicked Problems - Social Messes. Decision Support Modelling with Morphological Analysis. Springer-Verlag, Berlin, Acta Morphologica Generalis, 2:1-8.

Ritchey, T., 2015. Principles of cross-consistency assessment in morphological modelling. In: Acta Morphological Generalis, vol. 4.

Ritchey, T., 2018: General morphological analysis as a basic scientific modelling method. Technological Forecasting and Social Change, 126:81-91.

Sarvašová, Z., Dobšinská, Z., Šálka, J., 2014: Public participation in sustainable forestry: The case of forest planning in Slovakia. iForest - Biogeosciences and Forestry, 7:414-422.

Sarvašová, Z., Dobšinská, Z., 2016: Provision of ecosystem services in mountain forests - case study of experts' and stakeholders' perceptions from Slovakia. Journal of Forest Science, 62:380-387.

Schoemaker, P., 1995: Scenario Planning: A Tool for Strategic Thinking. Sloan Management Review, 36:25-40.

Schwartz, P., 1991: The Art of the Long View. Planing for the Future in an Uncertain World, New York, $272 \mathrm{p}$.

Tuček, J., Navrátil, R., Sedmák, R., Brodrechtová, Y., Smreček, R., 2015: Participatory scenarios and backcasting in strategic planning of forest management. Zvolen, Technical University in Zvolen, $332 \mathrm{p}$.
Vakula, J., 2011: State of Forest Health and Appearance of Harmful Factors in the Regions of Slovakia according to inspectors of Forest Protection Service for 2010. LOS.sk, [online 20. September 2015] URL: http://www.los.sk/zil.html

van Notten, P. W. F., Rotmans, J., van Asselt, M. B. A., Rothman, D. S., 2003: An updated scenario typology. Futures, 35:423-443.

Weccard,E. N., 2012: Future scenarios for the derivation of material requirements - the automobile interior 2030. University of Twente, NIKOS, Technische Universität Berlin, $91 \mathrm{p}$.

Wilson, C., Tansey, J., LeRoy, S., 2006: Integrating backcasting \& decision analytic approaches to policy formulation: a conceptual framework. Integrated Environmental Assessment and Management, 6:143-164.

Wollenberg, E., Edmunds, D., Buck, L., 1999: Using scenarios to make decisions about the future: Anticipatory learning for the adaptive co-management of community forests. Landscape Urban Plan, 47:65-77.

Wollenberg, E., Edmunds, D., Buck, L., 2000: Anticipating change: scenarios as a tool for adaptive forest management: a quide. Bogor, Indonesia, Centre for International Forestry Research, $38 \mathrm{p}$.

Zanoli, R., Gambelli, D., Vairo, D., 2012: Scenarios of the organic food market in Europe. Food Policy, 37: 41-57. 


\section{Appendix A: Characteristics of key factors and their variations for Podpolanie and Kysuce}

Table A1. Key factors used for designing the scenario space for CSA Podpol'anie.

\begin{tabular}{|c|c|c|}
\hline Code & Key factor & Factor description \\
\hline U1 & State of forests & $\begin{array}{l}\text { Up to } 90 \% \text { of forest stands in CSA represent mixed forests of temperate climate zone. Tree species composition is made up mainly } \\
\text { of spruce (61.9\%), beech ( } 30.7 \%) \text {, fir (1.5\%) and oak ( } 0.5 \%) \text { (Tuček et al. 2015). Due to very favourable climatic conditions, } \\
\text { the CSA is one of the most productive forest areas in Slovakia. It is dominated by intensely-cultivated even-aged stands in which } \\
\text { mainly shelterwood silvicultural system with an emphasis on natural regeneration is applied. Despite the occurrence of calamity } \\
\text { felling in the CSA, forest stands are relatively healthy and stable. The original tree species composition is predominant, but there } \\
\text { are also forest stands with artificially inserted spruce. }\end{array}$ \\
\hline $\mathrm{U} 2$ & Policies and legislation & $\begin{array}{l}\text { There are several strategic documents in Slovakia and two laws are of strategic significance for the forestry legislation: Act No } \\
326 / 2005 \text { Coll. on Forests and Act No 543/2002 Coll. on Nature and Landscape Protection. Implementation of the aforemen- } \\
\text { tioned laws causes forest management problems (e.g. dense network of various protected areas limits ownership rights by } \\
\text { environmental restrictions; NATURA } 2000 \text { partially overlaps with protected areas of the national level). The policies incoherence } \\
\text { situation is significant in Podpolanie, where a state forest ownership structure prevails and large protected areas exist (Brodrech- } \\
\text { tová et al. 2018). Compensations for financial loss due to nature protection restrictions is also problematic. }\end{array}$ \\
\hline U3 & Timber/Bioenergy market & $\begin{array}{l}\text { The wood sale is the most important source of income in the forestry sector in Slovakia (including CSA). Trends in the wood } \\
\text { processing industry thus significantly influence forestry enterprises and the forest management as well. The processing capacity } \\
\text { problems are encountered in Slovakia concerning the processing of deciduous round timber (e.g., beech and oak). As the beech } \\
\text { is considered to be the predominant tree species in CSA, this problem is significant to forestry income (Tuček et al. 2015). In con- } \\
\text { trast, the bioenergy market and biomass demand are growing in Slovakia and in CSA as well. A number of municipalities, towns or } \\
\text { companies and industrial plants with biomass heating plants is growing. Moreover, a strong interest in fuelwood biomass among } \\
\text { the population in the form of fuelwood and wood waste pellets remains in CSA. }\end{array}$ \\
\hline
\end{tabular}
The economic situation of forest owners is significantly influenced by the forest management costs associated with forest management and its planning. There are several types of costs that affect the economic situation of forest owners in CSA. Firstly, the costs associated with the inconsistency of policies and the bureaucracy directly affecting forest management measures. In the CSA, where more than $50 \%$ of the area is under the nature and landscape protection, the inconsistency and contradiction of forestry and environmental legislation are well demonstrated. Unclear procedures for liquidation of various calamities in forests (especially in

U4 Forest owner's economic protected areas), restrictions on the implementation of silvicultural measures create additional costs for forest management. Forsituation est stands surrounding the drink water reservoir Hriňová requires other additional costs related to special treatment for ensuring a purity of the water source. In addition, forestry enterprises are faced too often bureaucracy in relation to state administration. Disproportionate paperwork is a time-consuming factor, which reduces the productivity of enterprises and increases costs. This also applies to the process of financial compensations for the restriction in forest management due to nature protection. Next, there are operating costs associated with the practical implementation of silvicultural and forestry measures in forest stands. Forest owners sensitively perceive a gradual increase in total operating costs (Tuček et al. 2015).

The main important non-wood ES in CSA are Biodiversity Maintenance, Water Regulation/Clean Water, Recreation/Tourism and Hunting. The richness of the fauna and flora of CSA represents nearly 2700 species, of which 310 are protected by national legislation. The 174 bird species were identified and 128 nested in the territory. $32 \%$ of the region is part of the Polana Protected Landscape Area and $62 \%$ belongs to the NATURA2000 protected areas network (Tuček et al. 2015). Drink water reservoir Hriňová, located in CSA serves as a reservoir of drinking water for the water supply system of surrounding cities. Thus, the most Non-wood ecosystem services of the surrounding forest stands fall within the category of Special purpose forests with prevalent water management function. Management of such forests requires special treatment in order to ensure purity of the water source. The CSA is well known for its hunting tradition. The Protected Game Area of Pol'ana (area of more than 20000 ha) provides a coordinated ecological and large-scale management of the game. In addition, forests are used intensively for picking mushrooms and berries. Recreational activities, including hiking, cycling and winter sports, are also popular. Environmental restrictions significantly affect the forest owners and have a rather braking effect. Lack of financial resources is the main obstacle to the innovation process in forestry in Slovakia. Most forestry enterprises use subcontractors for silvicultural and harvesting operations. Due to short-term contracts, subcontractors face problems in fleet and mechanization renewal through loans, leasing, and so on. It affects the quality of the works carried out. The usage of obsolete ma-

U6 Innovation and technology chinery for working in forests has a negative impact on the environment as well. Due to the lack of funds, some forest enterprises do not perform silvicultural measures what may negatively affect the stability of forest ecosystems. Insufficient investments in the development and maintenance of forest road network influence the usability of felling-transport technologies and the overall cost. Overall, the innovation process in forestry stagnates and the transfer of the latest knowledge and research results into practice is still missing. The innovation cycle is too long, there is a lack of productive cooperation between research institutions and practice. In contrast to formal institutions (e.g., laws, regulations, standards, norms, rules), changes in informal institutions are going slower, are more problematic and resistant to adjustments of legislative measures. Impact of informal institutions is widespread across the society, as well as in the forestry sector, wood processing industry and the protection of the environment. It emerges

U7 Codes of conduct by the struggle for influence in this sector, promoting of interests of financial groups through political parties, political lobbying, clientelism, the occupation of political nominees into management functions, abusing of personal contacts and by non-transparent business practices. An unsuccessful fight against corruption, a slow shift in the culture of society and codes of conduct may negatively affect the institutions and state administration and the society as a whole.

Ownership of the forest land in CSA is split between state and non-state forestry entities. State enterprise Forests of the SR

G1 Forest ownership manages almost $85 \%$ of forests in the CSA. Thus, it is the strongest forestry subject in CSA. The largest share of non-state forest owners has communal (8.3\%) and private (3.2\%) ownership types. There is only a small part of municipal forests, church forests or forests still in the restitution process (unsolved ownership). 
Table A2. Key factors used for designing the scenario space for CSA Kysuce.

\begin{tabular}{llr}
\hline Code & Key factor & Factor description \\
\hline & Kysuce belongs to the Slovak territories with high forest cover and prevalen
\end{tabular}

Kysuce belongs to the Slovak territories with high forest cover and prevalence of the spruce. In the past, large spruce monocultures were established in the region, often even in places not suitable for spruce. Such stands have a low degree of ecological stability as

U1 State of forests well as of resistance to harmful factors. Lately, the area had been extensively affected by widespread necrosis of spruce stands (Kulla et al. 2009, Bošel'a et al. 2014) due to various abiotic, anthropogenic and biotic harmful factors such as honey fungus (Armillaria) and aggressive species of bark beetles (Hlásny \& Sitková 2010). These factors caused, that in 2010, the region was the area with the largest volume of calamity felling in Slovakia (Vakula 2011).

Forest land ownership in CSAis characterized by very high fragmentation: state forest owners (19\%), forests still in restitution process (unknown owners) managed by State enterprise Forests of the SR (34\%), and non-state forest owners including private, communal,

U2 Forest ownership municipal and church owners (46\%) (Navrátil et al. 2016). The restitution process, which began in 1991 has not yetbeen completed. Although the management of such forests is provided by state foresters, this situation causes many problems. For instance, highly fragmented forest ownership structure means a divergent interest of forest owners, various expertise and experience, management approaches, traditions, different financial options, human qualities or relationship to the forest.

approaches, traditions, different financial options, human qualities or relationship to the forest. opment Programme in SR for periods 2007-2013 and 2014-2020 should be achieved: (I.) improvement of the competitiveness of

U3 Subsidies agriculture, food industry and forestry by promoting restructuring, modernization, development and innovation, (II.) improving the environment and the quality of life in rural areas, and (III.) promoting diversification of economic activity. Financial resources from the EU Structural Funds are also an important financial instrument for innovations. These resources are almost unattainable for many small private forest owners in CSA due to bureaucracy and administrative burden. They sensitively perceive the incoherence of forestry and environmental legislation as well as unclear legislation on subsidies and financial compensation (Tuček et al. 2015). The economic situation of forest owners is significantly influenced by the forest management costs associated with forest management and its planning. There are several types of costs that affect the economic situation of forest owners in CSA: (1.) Costs associated with the critical health status of spruce forests in the region, the effects of harmful factors and spreading of bark beetles. The high

U4 Forest owner's economic situ- proportion of incidental felling, on one hand, increases a one-off income of forest owners. However, the income is lower because ation the wood is sold at lower quality. At the same time, problems are expected in the future, because of the lack of forest stands for logging. (2.) Total operating costs associated with the practical implementation of forestry measures. (3.) Costs associated with the inconsistency of forestry and environmental policies and legislation (e.g. unclear procedure for the liquidation of various calamities in forests located in protected areas).

Due to the high rate of calamity felling, excessive logging and high demand for wood in recentyears, it is expected that the total felling volume in CSA will be reduced by 2030 due to lack of wood. Since the sale of wood is the most important source of income for the

U5 Timber market forestry sector, it will have a significant impact on the regional forestry enterprises, wood-processing companies, the overall forest management and measures in CSA. Additionally, economic performance will depend on the demand for fuelwood and biomass as well as on political development.

In the majority of forestry enterprises in CSA, machinery equipment for the mechanization of harvesting and wood transportation does not correspond to still increasing demands for the reduction of negative environmental impacts. This is also reflected in the loss of the logged timber and poorer quality of assortments, which in turn leads to increased operating costs and reduced income. A high

U6 Innovation and technology proportion of calamity felling has another significant impact on applied harvesting technologies. Insufficient density and quality of forest road network causes an increase of skidding distance, what determines the usability of felling-transport technologies and affects the overall cost. By the majority of forest managers, the lack of financial sources is perceived as a main barrier in the innovation process. There is a mutual interaction between technological equipment and the level and quality of forestry measures implementation. Demographic development of last decades in Slovakia mirrors the EU trend of decreasing birth rates and a decline in mortality. In CSA, the population census in 2011 showed population decline for the first time in census history $(-1.2 \%$ in Čadca district and $-1.6 \%$ in Kysucké Nové Mesto district). The decline is due to an increased share of older people in the population while reducing the proportion of young people and people of working age. In Žilina region the ageing index increased in period 2001-2011 from 52.9 to 74.9 and for Kysucké Nové Mesto district rose to 76.3 (Tuček et al. 2015). Since the trend in demographic transition and ageing is likely to continue, it will bring challenges concerning the availability of a qualified workforce in the region. The reasons behind are twofold. First, the employment in agriculture, forestry and fisheries at the national and regional level is becoming less attractive. Second, in the population engaged in agriculture and forestry higher average age and lower qualifications dominate. 
Table A3. Variations of key factors used for designing the scenario space for CSA Podpolanie.

\begin{tabular}{|c|c|}
\hline \multicolumn{2}{|r|}{ Key factor U1: State of forests } \\
\hline \multirow{4}{*}{ U1a } & Stable and productive forests \\
\hline & - The stabilisation of changes in climate characteristics associated with a decrease in their variability. \\
\hline & - Slight changes in tree species composition. \\
\hline & $\begin{array}{l}\text { - The predominance of the principles of shelterwood silvicultural system with a special emphasis on natural forest regeneration. } \\
\text { - Possible formation of reliable plans in the strategic timeframe of rotation age. }\end{array}$ \\
\hline \multirow[b]{2}{*}{ U1b } & Present state \\
\hline & $\begin{array}{l}\text { - The trend of changes in climatic characteristics mirrors those of last years. } \\
\text { - Continuing strong influence of harmful factors, a high proportion of incidental felling and changes in tree species composition. } \\
\text { - Reliable planning is possible utmost for the tactical time frame (decade). }\end{array}$ \\
\hline \multirow[b]{2}{*}{ U1c } & Unstable forests \\
\hline & $\begin{array}{l}\text { - Unprecedentedly rapid changes of climate factors accompanied by the high frequency of occurrence of various extreme weather events (drought, heat waves, } \\
\text { windstorms). } \\
\text { - The strong influence of the entire spectrum of harmful factors and a high proportion of incidental felling. } \\
\text { - Significant changes in tree species compositions. Non-native forest stands are decaying and even the original forests are changing. } \\
\text { - Reliable tactical and strategic planning is practically impossible. }\end{array}$ \\
\hline \multirow[b]{3}{*}{$\mathrm{U} 2 \mathrm{a}$} & Key factor U2: Policies and legislation \\
\hline & Predominance environmental policy \\
\hline & $\begin{array}{l}\text { - Strong societal demands lead to enforcement of legislation favouring entire societal interests for nature conservation over the economic interests of current } \\
\text { forest owners. } \\
\text { - Introduction of legislation significantly increasing financial resources for nature protection management. } \\
\text { - Forest management activities of state and non-state forests owners are limited. } \\
\text { - Compensation for financial loss due to nature protection restrictions entirely paid to forests owners. }\end{array}$ \\
\hline \multirow[b]{2}{*}{$\mathrm{U} 2 \mathrm{~b}$} & Predominance forest policy \\
\hline & $\begin{array}{l}\text { - Strong political enforcement of the economic interests of forest owners over the interests of nature conservation. Despite partial harmonization of policies, } \\
\text { forest law takes over nature protection law. } \\
\text { - The forestry paradigm based on multi-purpose sustainable forest management, aimed at maximizing the volume production, even-flow and sustainable felling } \\
\text { by sustaining other non-productive functions of forests is politically enforced. }\end{array}$ \\
\hline \multirow[b]{2}{*}{$\mathrm{U} 2 \mathrm{c}$} & Policies incoherence \\
\hline & $\begin{array}{l}\text { - Discrepancies between foresters and environmentalists are even getting worse. } \\
\text { - Consistent lack of finances for protected areas management and compensation for financial loss due to nature protection restrictions. The State's obligation to } \\
\text { compensate financial losses to forests owners thus remains declarative. }\end{array}$ \\
\hline \multirow[b]{3}{*}{ U3a } & Key factor U3: Timber/Bioenergy market \\
\hline & Biomass demand growing \\
\hline & $\begin{array}{l}\text { - Rapidly growing demand for biomass due to rising prices of basic fuels and energy. } \\
\text { - Growing number of municipalities and companies equipped with biomass heating systems. } \\
\text { - Introduction of legislation fostering the biomass production on unused agricultural land and the establishment of energetic forest stands. }\end{array}$ \\
\hline \multirow[b]{2}{*}{$\mathrm{U} 3 \mathrm{~b}$} & Timber/Bioenergy demand growing \\
\hline & $\begin{array}{l}\text { - Growing timber demand due to the renaissance of wood processing and pulp/paper industry. } \\
\text { - Fostering the green economy (green buildings; higher use of wood beams; improvements in the use of composite materials) is driven by the higher support of } \\
\text { innovations and competitiveness. } \\
\text { - The persisting strong interest in biomass among the population and a growing number of municipalities with biomass heating systems. }\end{array}$ \\
\hline \multirow[b]{2}{*}{$\mathrm{U} 3 \mathrm{c}$} & Timber decreasing and Bioenergy stagnant \\
\hline & $\begin{array}{l}\text { - The price of input resources is increased twice as faster as production price causing pressure on the effectiveness of the wood processing industry. } \\
\text { - As banks perceive the wood processing industry as risky investment sector, no new investments are planned and lack of wood processing capacities expected. } \\
\text { - Stagnant demand for biomass due to stagnant fuels and energy prices and weak legislative and subsidies support for biomass. }\end{array}$ \\
\hline \multirow[b]{3}{*}{ U4a } & Key factor U4: The Forest owners' economic situation \\
\hline & Favourable \\
\hline & $\begin{array}{l}\text { - Better availability of subsidies through Rural Development policies as well as new supporting schemes introduced. } \\
\text { - The positive trends in timber and biomass markets result in increased income for forest owners. } \\
\text { - Better accessibility of compensation for financial loss due to nature protection restrictions and/or fulfilment of other ecosystem services. }\end{array}$ \\
\hline $\mathrm{U} 4 \mathrm{~b}$ & $\begin{array}{l}\text { Fluctuating } \\
\text { - Fluctuating trends timber and biomass markets cause unstable income for forest owners. } \\
\text { - Stagnant improvements in policy coherence and/or continuing only declarative character of Rural Development policies. } \\
\text { - Unclear subsidies scheme insecure forest managers and do not allow longer-term financial planning. }\end{array}$ \\
\hline $\mathrm{U} 4 \mathrm{c}$ & $\begin{array}{l}\text { Unfavourable } \\
\text { - Income from timber and biomass production is limited. } \\
\text { - Increased incoherency of forest and environmental policies and persisting absence of mutual cross-sectorial coordination. } \\
\text { - Weak accessibility to EU structural funds due to bureaucracy and administrative complexity. }\end{array}$ \\
\hline \multirow[b]{3}{*}{ U5a } & Key factor U5: Non-wood ecosystem services \\
\hline & Importance increasing \\
\hline & $\begin{array}{l}\text { - Increased broad societal pressure to foster sustainable forest management, greater emphasis on non-production ES and also to enhance the biodiversity and } \\
\text { nature protection as a whole. } \\
\text { - Non-wood ES becoming more attractive to forest owners, as a potential source of diversified income. } \\
\text { - Growing importance of clean water as a strategic resource causes the spreading of special purpose forests around the water reservoirs Hriňová and Málinec. }\end{array}$ \\
\hline \multirow[b]{2}{*}{ U5b } & Importance stagnant \\
\hline & $\begin{array}{l}\text { - Importance of ES reflects the present situation as there is a weak societal demand to change. } \\
\text { - The tourist infrastructure development is very weak, so the region's tourist potential is more-less stagnant. }\end{array}$ \\
\hline \multirow[b]{2}{*}{$\mathrm{U} 5 \mathrm{c}$} & The dominance of biodiversity maintenance \\
\hline & $\begin{array}{l}\text { - Policy instruments fully enforce the environmental paradigm that the natural evolution of the ecosystems is homeostatic and the best way of ensuring the } \\
\text { ecological stability of the forests is the strengthening of their biodiversity. Production ES are subdued and the preference is given to nature conservation. } \\
\text { - Passive forest management is associated with the strong limiting of any active forest management measures. } \\
\text { - Compensations for financial loss due to environmental restrictions are entirely paid to forest landowners. }\end{array}$ \\
\hline
\end{tabular}


Key factor U6: Innovation and technology

Improved situation

- Large investments in technology fleet renovation, the building of forest roads and other forestry infrastructure are emerging. This positively affects the quality of forest management measures.

- More effective cooperation between researchers and practitioners bringing the utilisation of procedures and facilities significantly affecting the quality and efficiency of forest management measures.

Stagnant situation

- General lack of financial sources is still the main barrier of technology innovations and is reflected in the overall stagnation and unfavourable situation in the field of innovation and technology.

- Transfer of the latest knowledge and research results into practice stagnate and the innovation cycle is still too long. Cooperation between researchers and practitioners is weak.

$$
\text { Key factor U7: Codes of conduct }
$$

Influence growing

- Growing struggle for influence in the forestry. Particularly, diverse political power affects the governmental and administrative authorities in forestry as well as in agricultural and environmental sector. Persisting impact of informal institutions and influence of financial groups in form of relying on the inherited system and on networking.

- Influence decreasing

U7b The pressure from the EU on institutional changes, transparency and the fight against corruption leads to the recovery of the entire society as well as the forestry sector.

- Decreasing in the impact of politicians, financial groups, lobbyists as well as informal institutions. Key factor G1: Forest ownership

G1a State ownership predominance

- State enterprise Forests of the SR is still the most important forestry entity in the CSA Podpolanie.

\begin{tabular}{|c|c|}
\hline \multicolumn{2}{|r|}{ Key factor U1: State of forests } \\
\hline & Young temporarily unprofitable stands \\
\hline U1a & $\begin{array}{l}\text { - The occurrence of large areas of even-aged mixed young forests incurred mainly by natural regeneration after the collapse of large complexes of non-native } \\
\text { spruce stands. } \\
\text { - Tree species composition of a new forest generation is generally more suitable, the mixed stands more correspond to the site and climatic conditions of the } \\
\text { region. On the other hand, forest stands have even-aged structure and due to natural regeneration and high production potential of sites in the region, the } \\
\text { density of forests is very high. } \\
\text { - The high intensity of tending is necessary to maintain the ecological stability of even-aged and dense forests. Despite the relatively high silviculture costs, the } \\
\text { ecological stability of forests is satisfactory. }\end{array}$ \\
\hline U1b & $\begin{array}{l}\text { Towards to Close to nature } \\
\text { - The occurrence of large areas of even-aged mixed young forests incurred mainly by natural regeneration after the collapse of large complexes of non-native } \\
\text { spruce stands. } \\
\text { - Due to the availability of subsidies, the numerous forest stands are under conversion from the even-aged structure, managed by clear-cut or shelterwood } \\
\text { system, to uneven-aged structure managed by more close-to-nature management (ideally by selection system). } \\
\text { - The ecological stability of forest stands with suitable species composition is guaranteed. }\end{array}$ \\
\hline U1c & $\begin{array}{l}\text { Unstable even-aged forests } \\
\text { - The occurrence of large areas of even-aged mixed young forests incurred mainly by natural regeneration after the collapse of large complexes of non-native } \\
\text { spruce stands. } \\
\text { - Due to lack of subsidies and fragmented ownership structure, the tending measures or conversions of young even-aged forest stands are not performed. Thus, } \\
\text { the ecological stability and health status of stands are getting worse. } \\
\text { - Fulfilment of production, economic and ecological management goals is strongly limited due to high management costs and lack of income. }\end{array}$ \\
\hline \multicolumn{2}{|r|}{ Key factor U2: Forest ownership } \\
\hline U2a & $\begin{array}{l}\text { Stabilization of small forest owner's status } \\
\text { - The strengthening of the rural state policy supported by subsidies helps to maintain fragmented agroforestry landscape. } \\
\text { - Private forest owners have no effort to sell their forests, although their forest stands are currently unprofitable. Due to subsidies, their motivation to maintain } \\
\text { the current agroforestry landscape character is increased. Subsidies help them to bridge an unfavourable period caused by loss of incomes from timber sales } \\
\text { and to focus on other non-productive functions and/or on biomass production. }\end{array}$ \\
\hline $\mathrm{U} 2 \mathrm{~b}$ & $\begin{array}{l}\text { Formation of larger owners } \\
\text { - Smaller private and communal owners sell their forest land. It is caused by the unfavourable state of forests that are currently unprofitable. Significantly } \\
\text { smaller income from the young forests stands is insufficient to meet the essential tending costs. } \\
\text { - Major strategic investors taking the opportunity to buy forest land at low prices are emerging. Financially strong investors are able to cover current higher costs } \\
\text { for forest stands tending as in the long-term they expect rising productivity of the forests. } \\
\text { - The regional municipalities and towns try to transfer the unknown owner forests into their ownership. }\end{array}$ \\
\hline $\mathrm{U} 2 \mathrm{c}$ & $\begin{array}{l}\text { Present state } \\
\text { - Continuation of fragmented forest ownership structure is expected in CSA. Despite some changes, the situation more or less reflects the current state. } \\
\text { - Large investors are not very interested in buying forest land. Smaller forest owners would like to sell/rent their unprofitable forest stands but the buyers/renters } \\
\text { are missing. }\end{array}$ \\
\hline \multicolumn{2}{|r|}{ Key factor U3: Subsidies } \\
\hline U3a & $\begin{array}{l}\text { Increased subsidies for rural development } \\
\text { - Strengthening of EU rural development policy in agriculture and forestry serve as a platform for economic diversification in rural communities. } \\
\text { - Adoption of New National Strategic Plan of Rural Development based on the evaluation of rural development programmes and increasing spending on } \\
\text { - Sorestry and agriculture. } \\
\text { - Significant increase and availability of financial instruments such as forest subsidy schemes appear. } \\
\text { - Compensations for financial loss due to environmental restrictions are entirely paid to forest landowners. }\end{array}$ \\
\hline
\end{tabular}

Table A4. Variations of key factors used for designing the scenario space for CSA Kysuce. 
Lack of subsidies

U3b - Stagnant and weak EU and national rural development policies reflected in the limited support of agricultural, forestry, biomass production or agro-tourism.

- Lack of financial instruments such as forestry subsidy schemes and low accessibility of compensation for financial loss due to nature protection restrictions and/or fulfilment of other ecosystem services.

\begin{tabular}{|c|c|}
\hline & Key factor U4: The Forest owners' economic situation \\
\hline \multirow[b]{2}{*}{ U4a } & Favourable \\
\hline & $\begin{array}{l}\text { - Better availability of subsidies through Rural Development policies as well as new supporting schemes introduced. } \\
\text { - Missing income from timber production is subsidized by income from biomass production as well as via new supporting schemes. } \\
\text { - New opportunities and entry of capital providing the additional income to the forest enterprises to conduct and improve their forest management measures. }\end{array}$ \\
\hline \multirow[b]{2}{*}{ U4b } & Fluctuating \\
\hline & $\begin{array}{l}\text { - Stagnating situation due to unmovable improvements in policy coherence and continuing declarative character of Rural Development policies. } \\
\text { - Fluctuating trends timber and biomass markets cause unstable income for forest owners. } \\
\text { - Unclear subsidies scheme insecure forest managers and do not allow longer-term financial planning. }\end{array}$ \\
\hline \multirow[b]{2}{*}{$\mathrm{U} 4 \mathrm{c}$} & Unfavourable \\
\hline & $\begin{array}{l}\text { - Young forest stands are unprofitable and require increased tending costs. Thus, profit from timber sale is limited regardless of the situation on the domestic } \\
\text { and foreign timber markets. } \\
\text { - The situation is also aggravated by the incoherence of forest and environmental policies and weak mutual cross-sectoral coordination. } \\
\text { - Minimal accessibility to EU structural funds for the majority of non-state forest owners due to bureaucracy and administrative complexity. }\end{array}$ \\
\hline \multicolumn{2}{|r|}{ Key factor U5: Timber market } \\
\hline & Lack of timber sources \\
\hline
\end{tabular}

U5a - Despite the growing timber demand, limited timber supplies (especially coniferous round-wood) in CSA endangers both forest owners and sawmills in the region.

- Persisting interest in fuelwood and biomass among the population, municipalities and companies with biomass heating systems.

Biomass production growing

U5b - Biomass production is supported by the adoption of new legislation in the field of renewable energy production. In particular, the legislation supporting wood biomass production on fallow agricultural land (e.g. short-term forestry) and the establishing of energy forests among others are introduced.

- Strong interest in fuelwood and biomass among the population, municipalities and companies with biomass heating systems.

Key factor U6: Innovation and technology

Improved situation

- Large investments in technology fleet renovation, the building of forest roads and other forestry infrastructure are emerging. This positively affects the quality

U6a of forest management measures.

- Appropriate mechanization of works in young forest stands together with better forest stands accessing multiply the utilization of the production potential of biomass for energy purposes. Additionally, capacities for biomass processing are built in the region.

Stagnant situation

U6b - General lack of financial sources is still the main barrier to technology innovations.

- Since the investments in forestry are deeply undersized, the vehicle fleet is obsolete, forest roads network is uneven and neglected the utilised tending and felling-transport methods are inappropriate. It also brings obstacles to the utilization of the production potential of biomass for energy purposes.

Key factor U7: Population

- The improved situation in rural development thanks to supporting of forestry and agricultural activities, agro-tourism as well as the support of renewable energy production mainly from biomass.

U7a - There are new employment opportunities, improved infrastructure of villages, protection and development of social capital and the rural cultural heritage, and availability of raw biomass materials for the implementation of renewable energy policies.

- Raising attractiveness of the majority of rural settlements causing stabilisation of rural population and increased interest in employment in forestry and agriculture.

Lack of qualified labour

- Weak support in the rural development, forestry and agricultural activities, agro-tourism as well as the support of renewable energy production from biomass.

U7b - Low interest in employment in forestry and agriculture and migration of young people from the countryside in some areas resulting in reducing of availability of qualified available labour. There is a predominance of older and less qualified workers in forestry and agricultural in CSA.

Depopulation of rural areas

U7c - No support in the rural development, forestry and agricultural activities, agro-tourism as well as the support of renewable energy production from biomass.

- Migration of young people from the countryside reduces the availability of qualified labour and create unfavourable demographic structure. Along with the population ageing it causing the depopulation of the region. 